\title{
APLIKASI PENENTUAN TINGKAT KEPUASAN MAHASISWA TERHADAP LAYANAN PENDIDIKAN BERBASIS FUZZY
}

\author{
Freska Rolansa ${ }^{1}$, Suheri ${ }^{2}$ \\ 1,2Program Studi Teknik Informatika Politeknik Negeri Pontianak, \\ 1,2JL. Ahmad Yani Pontianak \\ ${ }^{1}$ Email: freska.ilkom@gmail.com
}

\begin{abstract}
Abstrak
Mahasiswa merupakan Konsumen utama di Program Studi (Prodi) Teknik Informatika (TI) Kepuasan Layanan Mahasiswa sangat penting dan mendasar dalam meningkatkan kualitas program studi. Kepuasan mahasiswa dapat dijadikan indikator /bahan evaluasi dalam pencapaian visi dan misi Prodi TI. Kesulitan dalam melakukan pengukuran kepuasan mahasiswa terhadap layanan di program studi Teknik informatika merupakan masalah yang harus diselesaikan. Rendahnya kepuasan mahasiswa terhadap layananmemperlambat kinerja dan bahkan mengganggu aktivitas proses belajar mengajar di Prodi TI. Aplikasi Pengukur Tingkat Kepuasan Mahasiswa terhadap Layanan di Program Studi Teknik Informatika Politeknik Negeri Pontianak berbasis Fuzzy dibuat dengan mengumpulkan data terkait pengukuran kepuasan mahasiswa, kemudian dilakukan analisis dengan metode service quality, setelah itu dilakukan perancangan aplikasi berbasis fuzzy dan setelah itu diimplementasikan di prodi TI untuk melakukan Evaluasi terhadap layanan
\end{abstract}

Kata Kunci: Aplikasi Fuzzy, Evaluasi, Kepuasan Mahasiswa, Layanan

\begin{abstract}
Students are the primary Consumers at the Informatics Engineering Study Program (IT). Student Service Satisfaction is very important and fundamental in improving the quality of study programs. Students' satisfaction can be used as an indicator / evaluation material of accomplishment of vision and mission. The difficulty in measuring Student Service Satisfaction at the Informatics Engineering Study Program was a problem to be solved. The low level of student Service Satisfaction slows down performance and even disrupted the teaching and learning activities in IT Study Programs. Application of Measuring Levels of Student Service Satisfaction in Fuzzy Informatics Engineering Study Program based on Fuzzy in Politeknik Negeri Pontianak was made by collecting data related to measuring students' satisfaction, then analyzed by service quality method, after fuzzy based application design was carried out, it was implemented in IT study programs to conduct an Evaluation of services.
\end{abstract}

Keywords: Fuzzy Application, Evaluation, Student Satisfaction, Service 


\section{PENDAHULUAN}

Pendidikan merupakan kegiatan komunikasi dalam penyampaian dan pertukaran pesan pada peserta didik. Perguruan tinggi menyelenggarakan proses belajar mengajar, penelitian serta pengabdian kepada masyarakat yang merupakan Tridharma Perguruan Tinggi. Program Studi Teknik Informatika (Prodi TI) Politeknik Negeri Pontianak merupakan sebuah instansi pemerintah yang bergerak dibidang pendidikan. Jumlah total mahasiswa di Prodi TI saat ini lebih dari 200 mahasiswa (Polnep dalam angka, 2017). Jumlah mahasiswa yang banyak merupakan kewajiban bagi Prodi TI dalam memberikan layanan yang memberikan kepuasan kepada mahasiswa. Jenis layanan yang diberikan kepada mahasiswa berupa bimbingan dan konseling pada saat perkuliahan maupun dalam perkembangan akademik mahasiswa, pengembangan minat dan bakat, pembinaan soft skills, bantuan beasiswa dan perawatan dan pengobatan kesehatan mahasiswa.

Mahasiswa merupakan Konsumen utama di Prodi TI, dan kepuasan Mahasiswa sangat penting dan mendasar dalam meningkatkan kualitas prodi selain itu kepuasan mahasiswa dapat dijadikan indikator/bahan evaluasi dalam pencapaian visi dan misi Prodi TI. Visi prodi TI adalah tahun 2020, Program Studi Teknik Informatika merupakan penyelenggara pendidikan profesional di bidang teknologi informasi yang memiliki komperaktif dan kompetitif, baik di tingkat nasional maupun internasional dalam bidang penelitian terapan, menghasilkan lulusan yang berpengetahuan, terampil dan berkepribadian untuk mensejahterakan masyarakat. Misinya adalah Menyelenggarakan Pendidikan Profesional, mengembangkan dan menerapkan ilmu pengetahuan dan teknologi di bidang teknologi informasi dalam upaya meningkatkan kesejahteraan masyarakat serta menunjang pembangunan daerah dan nasional dengan memberdayakan program studi secara maksimal

Pada Prodi TI, tingkat kepuasan layanan mahasiswa saat ini diukur dengan menggunakan Kuesioner yang disebarkan sewaktu mahasiswa akan melaksanakan ujian akhir disetiap semester. Prodi TI belum memiliki sebuah wadah yang dapat mengukur tingkat kepuasan mahasiswa yang dikemas dalam bentuk aplikasi. Aplikasi ini dapat membantu dalam memudahkan dokumentasi, penyimpanan 
kuesioner serta pengolahan hasil kuesioner berbasis Fuzzy untuk mengukur kepuasan layanan.

Teori himpunan fuzzy diperkenalkan pertama kali oleh Lotfi A. Zadeh pada tahun 1965. Ada beberapa alasan mengapa orang menggunakan logika fuzzy, antara lain yaitu konsep logika fuzzy mudah dimengerti, logika fuzzy sangat fleksibel, logika fuzzy memiliki toleransi terhadap data-data yang tidak tepat (Turban, 2015), logika fuzzy mampu memodelkan fungsi-fungsi nonlinear yang sangat kompleks, logika fuzzy dapat membangun dan mengaplikasikan pengalaman-pengalaman para pakar secara langsung tanpa harus melalui proses pelatihan, logika fuzzy dapat juga digunakan dalam pendukung pengambilan keputusan (Kusrini, 2002) dalam analisis kepuasan siswa (Hamdi, 2015).

Oleh karena itu, melihat pentingnya tingkat kepuasan mahasiswa maka dibutuhkan sebuah sistem yang dapat digunakan untuk mengukur tingkat kepuasan mahasiswa dalam melakukan evaluasi terhadap peningkatan proses belajar mengajar di Prodi TI berbasis Fuzzy.

\section{METODE}

Data terkait pengukuran Kepuasan Mahasiswa diperoleh dari studi literatur maupun eksplorasi jurnal di internet, serta penyusunan dan rekapitulasi hasil kuesioner. Selanjutnya data dianalisis berdasarkan analisis kebutuhan sistem. Hasil dari analisis kebutuhan sistem ini diperlukan sebagai acuan dalam menyusun spesifikasi sistem yang akan dikembangkan. Langkah-langkah yang dilakukan pada tahap analisis adalah memahami sistem yang sudah dan sedang berjalan, mengidentifikasi permasalahan pada sistem yang sedang berjalan dan menarik kesimpulan dari proses analisis yang telah dilakukan. Pada tahap ini dibuat Kuesioner Kepuasan Mahasiswa terhadap Layanan berdasarkan Harapan dan Persepsi/Kenyataan serta dilihat GAP berdasarkan metode Service Quality (SERVQUAL) terhadap 5 faktor yaitu Reliability (Kehandalan Dosen dan Staf Akademik), Tangible (Sarana pendidikan-Alat perkuliahan, Media Pengajaran dan Prasarana Pendidikan), Responsiveness (Sikap tanggap), Assurance (Perlakuan 
terhadap mahasiswa) dan Emphaty (Pemahaman terhadap kepentingan mahasiswa).

Setelah dilakukan analisis, kebutuhan-kebutuhan yang didefinisikan dalam tahap analisis lalu diterjemahkan ke dalam bentuk model presentasi sistem aplikasi, dengan merancang input, proses dan output dalam menggunakan aplikasi. Tahap perancangan dilakukan guna memudahkan tahap berikutnya yakni tahap implementasi. Tahap perancangan sistem Fuzzy mencakup rancangan fungsi Keanggotaan, Fuzzifikasi, penentuan rule, dan Defuzifikasi sesuai kebutuhan pengembangan aplikasi

Tahap implementasi sistem merupakan pengaplikasian bentuk sistem yang akan dirancang ke dalam bahasa program tertentu dan mengkombinasikan Metode Service Quality dengan Logika Fuzzy untuk menghasilkan sistem aplikasi. Tahap implementasi merupakan tahap meletakkan sistem supaya siap untuk dioperasikan.

\section{HASIL DAN PEMBAHASAN}

Kuesioner yang telah disusun terdiri atas 27 pertanyaan dengan jawaban skala 1-5 Variabel Harapan dan Variabel Kenyataan terhadap Layanan Pendidikan di Program Studi Teknik Informatika dapat dilihat pada Gambar 1.

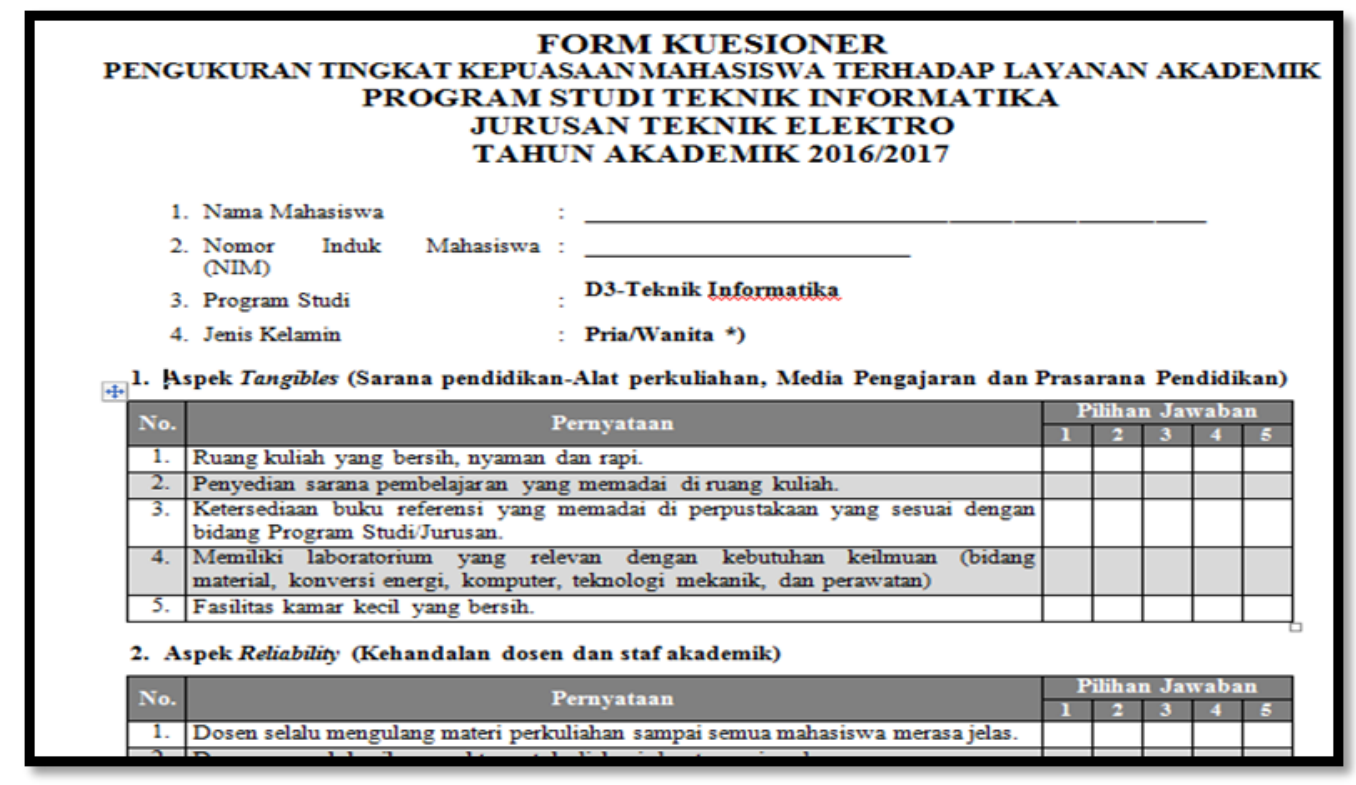

Gambar 1. Kuesioner Layanan Akademik 
Berdasarkan hasil Kuesioner yang disebarkan kepada 15 mahasiswa yang masih aktif kuliah di Prodi TI diperoleh hasil seperti terlihat pada Gambar 2.

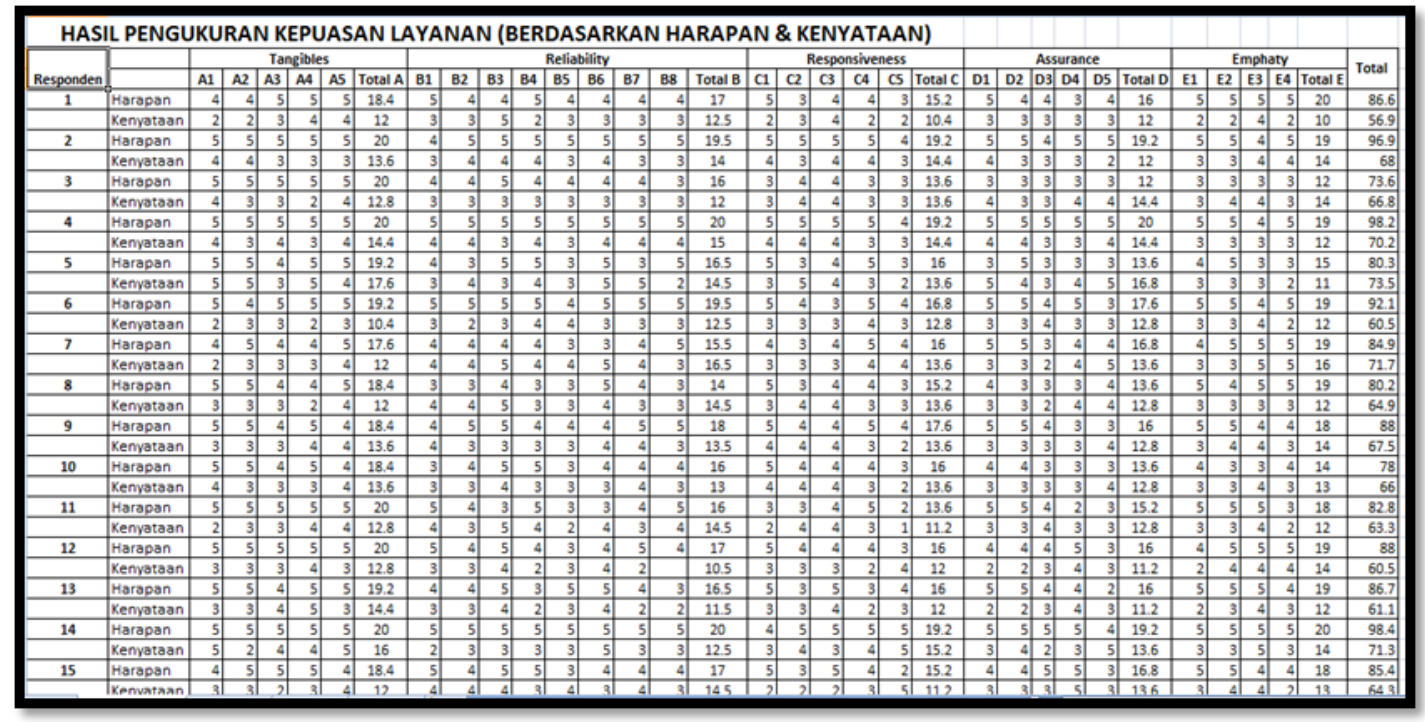

Gambar 2. Hasil Kuesioner 15 Mahasiswa

Setelah itu dilakukan perhitungan antar dimensi pada Metode Service Quality, dengan mencari Nilai Gap Servqual. Hasil perhitungan menunjukkan bahwa Dimensi Tangible memiliki Nilai GAP terbesar, yang berarti dimensi inilah yang belum terpenuhi terhadap kualitas layanan seperti yang diharapkan, seperti dilihat pada Gambar 3.

\begin{tabular}{|r|l||r|r|r|r|}
\hline \multirow{2}{*}{ No } & \multirow{3}{*}{ Dimensi } & \multicolumn{3}{|c|}{ Rata Rata } & \multicolumn{2}{c|}{$\begin{array}{c}\text { Fuzzy } \\
\text { servqual }\end{array}$} \\
\cline { 3 - 6 } & Harapan & Kenyataan & Servqual & 17 \\
\hline 1 & Tangible & 19.147 & 13.333 & -5.813 & 17 \\
\hline 2 & Reliability & 17.233 & 13.433 & -3.800 & 17 \\
\hline 3 & Responsiveness & 16.320 & 13.013 & -3.307 & 17 \\
\hline 4 & Assurance & 16.107 & 13.120 & -2.987 & 17 \\
\hline 5 & Emphaty & 17.867 & 12.867 & -5.000 & \\
\hline
\end{tabular}

\section{Gambar 3. Selisish GAP pengukuran}


Berdasarkan Konsep Fuzzy, tahapan untuk memperoleh hasil yang akan mendukung hasil evaluasi terhadap kepuasan mahasiswa yakni Fuzzifikasi dengan menentukan Fungsi Keanggotaan terhadap variabel input dan variabel Output, Penentuan rule sebagai inferensi sistem dan tahap defuzifikasi.

\section{Fuzzifikasi}

Input Keanggotaan

Berikut ini adalah cara untuk mendapatkan hasil keanggotaan berdasarkan variabel linguistik dan variabel numerik:

Fungsi keanggotaan himpunan fuzzy dari variabel Harapan: Sangat Tidak Penting (STP), Tidak Penting (TP), Cukup Penting (CP), Penting (P), dan Sangat Penting (SP). Berikut ini adalah persamaan masing-masing fungsi keanggotaannya:

$\mu$ HARAPAN STP $[x]=\left\{\begin{array}{cl}1 & ; x<20 \\ \frac{(35-x)}{(15)} ; & 20<x<35 \\ 0 & ; x \geq 35\end{array}\right.$

$\mu$ HARAPAN TP $[x]=\left\{\begin{array}{l}0 \quad ; x \leq 20 \text { atau } x \geq 50 \\ \frac{(x-20)}{(15)} ; 20<x<35 \\ \frac{(50-x)}{(15)} ; 35<x<50\end{array}\right.$

$\mu$ HARAPAN $C P[x]=\left\{\begin{array}{l}0 \quad ; x \leq 35 \text { atau } x \geq 65 \\ \frac{(x-35)}{(15)} ; 35<x<50 \\ \frac{(65-x)}{(15)} ; 50<x<65\end{array}\right.$

$\mu$ HARAPAN $P[x]=\left\{\begin{array}{l}0 \quad ; x \leq 50 \text { atau } x \geq 80 \\ \frac{(x-50)}{(15)} ; 50<x<65 \\ \frac{(80-x)}{(15)} ; 65<x<80\end{array}\right.$ 
$\mu$ HARAPAN SP $[x]\left\{\begin{array}{cc}0 & ; x<65 \\ \frac{(x-65)}{(15)} ; 65<x<80 \\ 1 & ; x \geq 80\end{array}\right.$

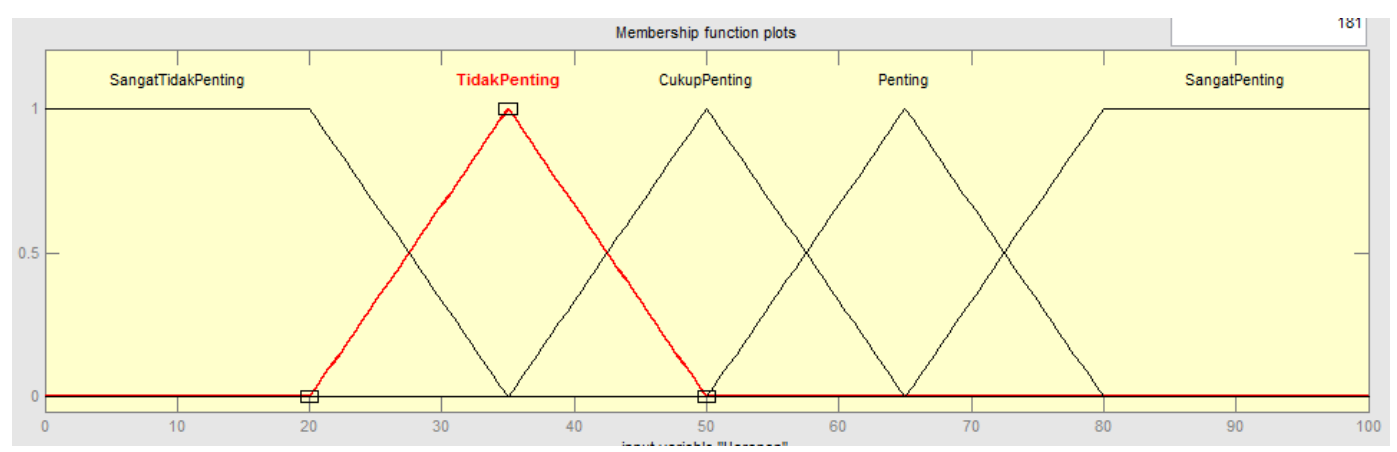

Gambar 4. Fungsi Keanggotaan Variabel Harapan

Fungsi keanggotaan himpunan fuzzy dari variabel Persepsi: Sangat Tidak Puas (STP), Tidak Puas (TP), Cukup Puas (CP), Puas (P), dan Sangat Puas (SP). Berikut ini persamaan masing-masing fungsi keanggotaannya:

$$
\begin{aligned}
& \mu \text { PERSEPSI STP }[y]=\left\{\begin{array}{c}
1 \\
\frac{(35-y)}{(15)} ; 20<y<35 \\
0 \quad ; y \geq 35
\end{array}\right. \\
& \mu \text { PERSEPSI TP }[y]=\left\{\begin{array}{l}
0 \quad ; y \leq 20 \text { atau } y \geq 50 \\
\frac{(y-20)}{(15)} ; 20<y<35 \\
\frac{(50-y)}{(15)} ; 35<y<50
\end{array}\right. \\
& \mu \text { PPERSEPSI CP }[x]=\left\{\begin{array}{l}
0 \quad ; y \leq 35 \text { atau } y \geq 65 \\
\frac{(y-35)}{(15)} ; 35<y<50 \\
\frac{(65-y)}{(15)} ; 50<y<65
\end{array}\right.
\end{aligned}
$$




$$
\begin{aligned}
& \mu \text { PERSEPSI } P[y]=\left\{\begin{array}{l}
0 \quad ; y \leq 50 \text { atau } y \geq 80 \\
\frac{(y-50)}{(15)} ; 50<y<65 \\
\frac{(80-y)}{(15)} ; 65<y<80
\end{array}\right. \\
& \mu \text { PERSEPSI SP }[y]\left\{\begin{array}{cc}
0 & ; y<65 \\
\frac{(y-65)}{(15)} ; 65<y<80 \\
1 & ; y \geq 80
\end{array}\right.
\end{aligned}
$$

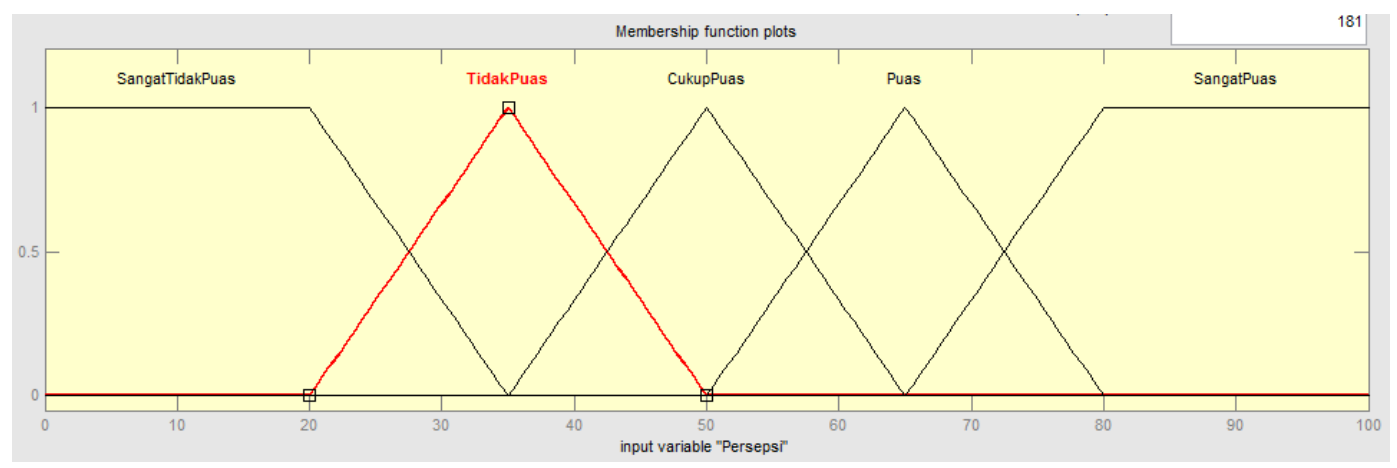

\section{Gambar 5 Fungsi Keanggotaan variabel Persepsi}

Output Keanggotaan

Fungsi keanggotaan himpunan fuzzy dari variabel Layanan :Tidak Baik (TB), Baik (B), dan Sangat Baik (SB). Berikut ini persamaan masing-masing fungsi keanggotaannya:

$$
\begin{gathered}
\mu \text { Layanan } T B[z]=\left\{\begin{array}{lc}
1 & ; z \leq 20 \\
\frac{(50-z)}{(30)} ; & 20<z<50 \\
0 & ; z \geq 50
\end{array}\right. \\
\mu \text { Layanan } B[z]=\left\{\begin{array}{lc}
0 \quad ; z \leq 20 \text { atau } z \geq 80 \\
\frac{(z-20)}{(30)} ; 20<z \leq 50 \\
\frac{(80-z)}{(30)} & ; 50<z \leq 80
\end{array}\right.
\end{gathered}
$$


$\mu$ Layanan $S B[z]=\left\{\begin{array}{cc}0 & ; z<50 \\ \frac{(z-50)}{(30)} ; & 50<z<80 \\ 1 & ; z \geq 80\end{array}\right.$

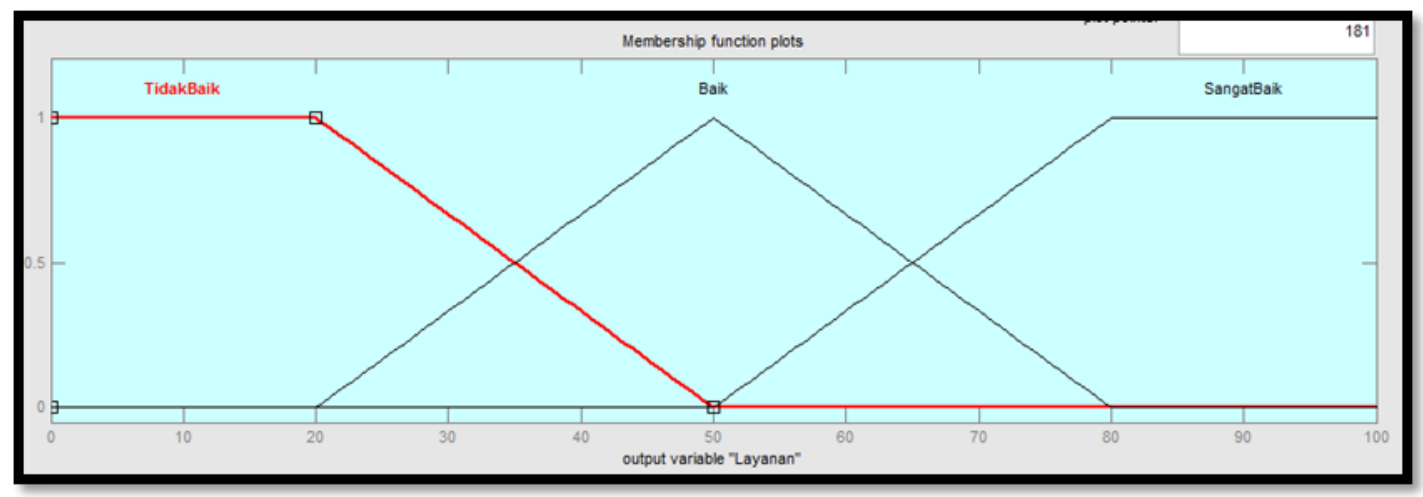

Gambar 6. Fungsi keanggotaan Variabel Layanan

Setelah ditentukan input dan output dari keanggotaan fuzzy, dilakukan tahapan inferensi seperti dilihat pada Gambar 6.

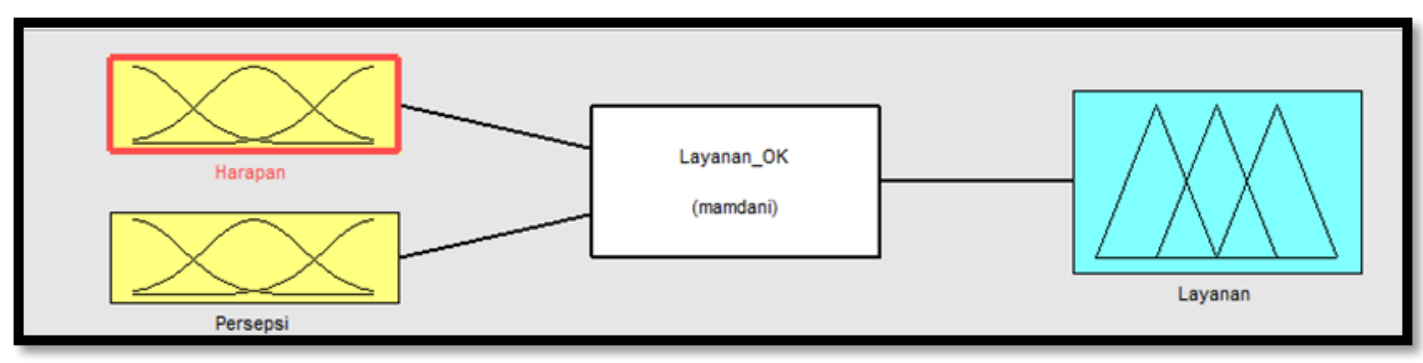

\section{Gambar 7. Inferensi Fuzzy Layanan}

\section{Penentuan Rule}

Setelah fungsi keanggotaan Input dan Output dibuat maka ditentukan Rule-Rule sebagai inferensi sistem yang telah dibuat dengan melakukan Komposisi, seperti terlihat pada Gambar 8. 
1. If (Harapan is TidakPenting) and (Persepsi is TidakPuas) then (Layanan is TidakBaik) (1)

2. If (Harapan is TidakPenting) and (Persepsi is CukupPuas) then (Layanan is Baik) (1)

3. If (Harapan is TidakPenting) and (Persepsi is Puas) then (Layanan is Baik) (1)

4. If (Harapan is TidakPenting) and (Persepsi is SangatTidakPuas) then (Layanan is TidakBaik) (1)

5. If (Harapan is TidakPenting) and (Persepsi is SangatPuas) then (Layanan is Baik) (1)

6. If (Harapan is CukupPenting) and (Persepsi is CukupPuas) then (Layanan is Baik) (1)

7. If (Harapan is Penting) and (Persepsi is Puas) then (Layanan is Baik) (1)

8. If (Harapan is SangatTidakPenting) and (Persepsi is TidakPuas) then (Layanan is TidakBaik) (1)

9. If (Harapan is SangatPenting) and (Persepsi is CukupPuas) then (Layanan is Baik) (1)

10. If (Harapan is SangatPenting) and (Persepsi is Puas) then (Layanan is SangatBaik) (1)

11. If (Harapan is SangatPenting) and (Persepsi is SangatPuas) then (Layanan is SangatBaik) (1)

12. If (Harapan is SangatTidakPenting) and (Persepsi is Puas) then (Layanan is Baik) (1)

12 If (Haranan is Pentinn) and (Persensi is Puas) then (I avanan is Raik) (1)

\section{Gambar 8. Rule Inferensi}

\section{Defuzifikasi}

Pada sistem ini digunakan defuzifikasi menggunakan metode bisektor dengan cara mengambil nilai pada domain fuzzy yang memiliki nilai keanggotaan setengah dari jumlah total nilai keanggotaan pada daerah fuzzy.

Contoh hasil input harapan dengan nilai 86.6 dan persepsi 56.9 menghasilkan output layanan 62 dengan Fuzzy Servqual seperti terlihat pada Gambar 9.

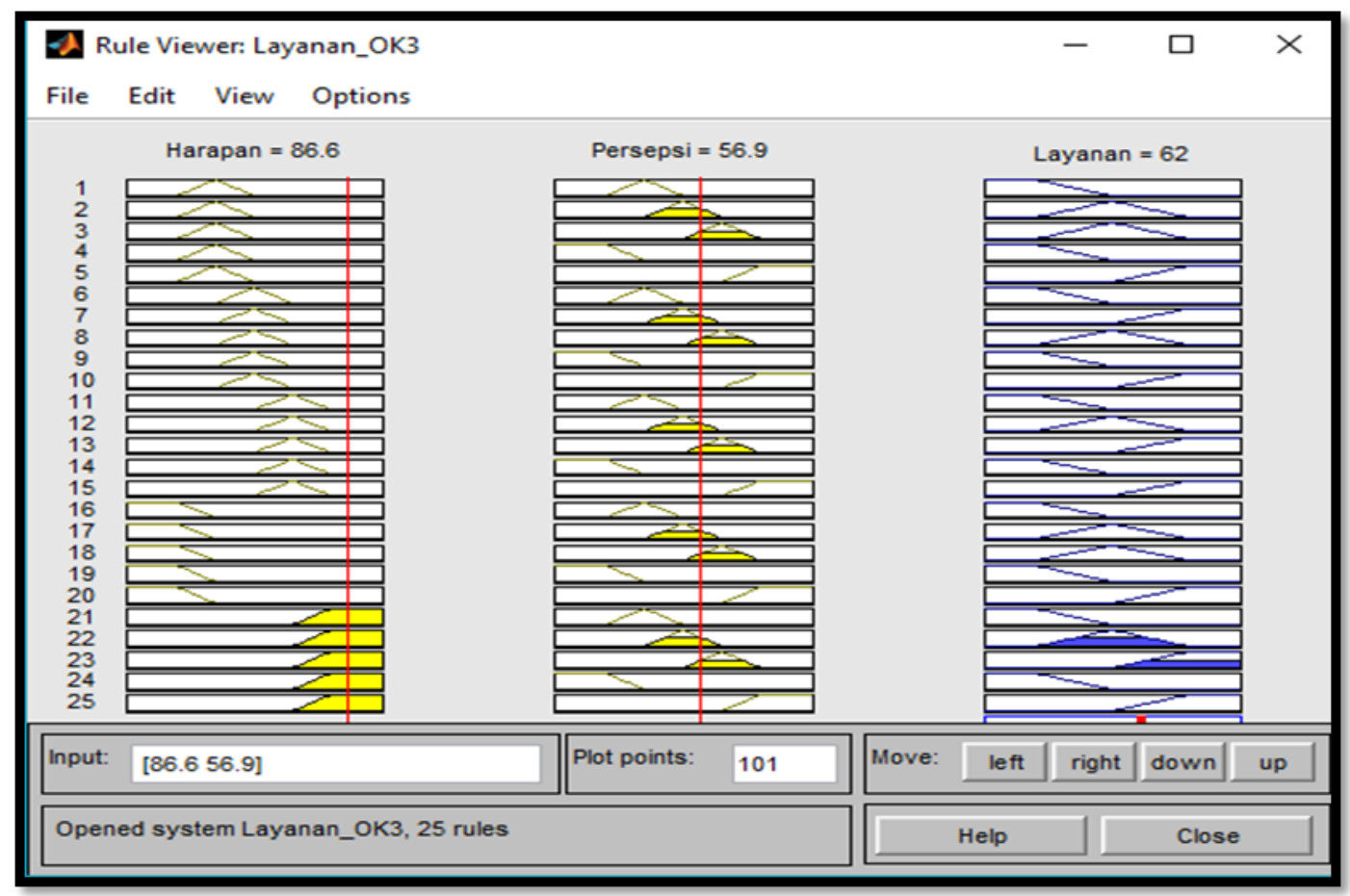

\section{Gambar 9. Input data Korespondensi 1}

Data keseluruhan dengan pengisian dari 15 respondensi dan dihitung masing-masing nilai fuzzy sevqual disajikan pada Gambar 10. 


\begin{tabular}{|c|c|c|c|}
\hline \multirow[b]{2}{*}{ Responden } & \multicolumn{2}{|c|}{ Rata Rata Skor } & \multirow{2}{*}{\begin{tabular}{|l|} 
Fuzzy \\
Servqual \\
\end{tabular}} \\
\hline & Harapan & Persepsi & \\
\hline 1 & 86.6 & 56.9 & 62 \\
\hline 2 & 96.9 & 68 & 81 \\
\hline 3 & 73.6 & 66.8 & 80 \\
\hline 4 & 98.2 & 70.2 & 80 \\
\hline 5 & 80.3 & 73.5 & 79 \\
\hline 6 & 92.1 & 60.5 & 74 \\
\hline 7 & 84.9 & 71.7 & 79 \\
\hline 8 & 80.2 & 64.9 & 83 \\
\hline 9 & 88 & 67.5 & 81 \\
\hline 10 & 78 & 66 & 82 \\
\hline 11 & 82.8 & 63.3 & 80 \\
\hline 12 & 88 & 60.5 & 74 \\
\hline 13 & 86.7 & 61.1 & 71 \\
\hline 14 & 98.4 & 71.3 & 80 \\
\hline 15 & \begin{tabular}{|r|}
85.4 \\
\end{tabular} & 64.3 & 82 \\
\hline \multicolumn{3}{|c|}{ Rata-Rata } & 77.8667 \\
\hline
\end{tabular}

\section{Gambar 10. Data Fuzzy Servqual}

Berdasarkan Gambar 10 maka dapat diambil kesimpulan yakni pelayanan akademik di Program Studi Teknik Informatika dinilai Baik. Hal ini ditunjukan dengan skor rata-rata nilai fuzzy servqual yang didapat dari 15 orang mahasiswa Prodi TI sebagai responden menunjukkan angka [77,86] dengan rentang penilaian [0..100], Hasil ini berarti Fungsi keanggotaan Output Layanan Baik (Nilai = 0,07) dan dan Fungsi keanggotaan Output pelayanan Sangat Baik (Nilai = 0,93).

\section{SIMPULAN}

Aplikasi Penentuan Tingkat kepuasan Mahasiswa terhadap layanan pendidikan di program studi Teknik Informatika membantu dalam melakukan pengukuran terhadap quality service berdasarkan faktor 5 faktor yaitu yaitu Reliability (Kehandalan Dosen dan Staf Akademik), Tangible (Sarana pendidikanAlat perkuliahan, Media Pengajaran dan Prasarana Pendidikan), Responsiveness (Sikap tanggap), Assurance (Perlakuan terhadap mahasiswa) dan Emphaty (Pemahaman terhadap kepentingan mahasiswa) dan uji coba yang dilakukan menghasilkan bahwa Kualitas Layanan di Program Studi Teknik Informatika bernilai Sangat baik.terhadap 15 responden dengan nilai $=0,93$, akan tetapi GAP 
yang memiliki nilai selisih terbesar pada Dimensi Tangible, artinya pada dimensi ini harus diperhatikan untuk perbaikan.

\section{DAFTAR PUSTAKA}

Hamdi. K, (2015). Sistem Pendukung Keputusan dalam Menganalisa Tingkat Kepuasan Siswa terhadap Fasilitas Sekolah Menggunakan Logika Fuzzy (Studi Kasus SMK Negeri 2 Padang).

Harto. B. (2015). Analisis Tingkat Kepuasan Pelanggan Dengan Pendekatan Fuzzy Servqual Dalam Upaya Peningkatan Kualitas Pelayanan (Studi Kasus Di Bengkel Resmi BAJAJ Padang), Jurnal TEKNOIF, Vol. 3 No. 1 April 2015

Kusrini. (2002). Konsep dan Aplikasi Sistem Pendukung Keputusan. Yogyakarta : Andi Offset.

Kusumadewi, Sri \& Purnomo, Hari. (2010). Aplikasi Logika Fuzzy. Yogyakarta: Graha Ilmu.

Pratiwi. I. (tanpa tahun). Analisis Kepuasan Konsumen Berdasarkan Tingkat Pelayanan Dan Harga Kamar Menggunakan Aplikasi Fuzzy dengan Matlab 3.5. Jurusan Teknik Industri, Universitas Muhammadiyah Surakarta

Sri Yulianto J.P., Indrastanti R.W., Martha Oktriani. (2008). Aplikasi Pendukung Keputusan Dengan Menggunakan Logika Fuzzy (Studi Kasus : Penentuan Spesifikasi Komputer Untuk Suatu Paket Komputer Lengkap). Jurnal Informatika, Vol.4, No. 2, Desember 2008: 159 - 173

Turban, (2005), Decision Support Systems and Intelligent Sistems (Sistem Pendukung Keputusan dan Sistem Cerdas), Andi : Yogyakarta. 